zdolności, ponieważ coraz częściej w zarządzaniu uczelnią wykorzystuje się skomplikowane struktury danych, które trzeba prosto i przekonywająco przedstawić różnym słuchaczom, także decydentom i donatorom. Humanistyka cyfrowa ma wiele wymiarów, a wizualizacje są jednym z ciekawszych.

Veslava Osińska Instytut Informacji Naukowej i Bibliologii, Uniwersytet Mikołaja Kopernika w Toruniu

Bożena Bednarek-Michalska

Biblioteka Uniwersytecka, Uniwersytet Mikołaja Kopernika w Toruniu

\title{
IV Międzynarodowa Konferencja Naukowa „Nauka o informacji (informacja naukowa) w okresie zmian" Innowacyjne usługi informacyjne (Warszawa, 15-16 maja 2017 r.)
}

W dniach 15-16 maja 2017 r. w salach Biblioteki Uniwersyteckiej w Warszawie odbyła się czwarta już edycja międzynarodowej konferencji naukowej „Nauka o informacji (informacja naukowa) w okresie zmian". Jest to konferencja organizowana cyklicznie co dwa lata przez dawny Zakład Systemów Informacyjnych Instytutu Informacji Naukowej i Studiów Bibliologicznych Uniwersytetu Warszawskiego. W tym roku po raz pierwszy zorganizowana została pod szyldem nowej jednostki uniwersyteckiej: Katedry Informatologii Wydziału Dziennikarstwa, Informacji i Bibliologii UW.

Tematem przewodnim tegorocznego spotkania były innowacyjne usługi informacyjne. Wszyscy na co dzień doświadczamy zmian, jakie zachodzą w naszym otoczeniu informacyjnym. Przemianom ulegają kanały komunikacyjne, media, sposoby przekazywania, ale także konsumowania czy wykorzystywania informacji; zmieniają się technologie, kontekst społeczny, oczekiwania i role użytkowników informacji. Usługi informacyjne są jednym z tych fragmentów pola zainteresowań informatologii, o których najbardziej zasadnie można powiedzieć, że znajdują się w okresie zmian.

Zakres tematyczny konferencji, określony przez Komitet Programowy, objął szeroką gamę teoretycznych i praktycznych aspektów użytkowania nowoczesnych narzędzi i metod działalności informacyjnej, organizacji i zarządzania informacją i wiedzą, analizy i oceny nowych technologii wykorzystywanych w społecznym transferze informacji i wiedzy oraz ich recepcji wśród użytkowników. Przyjęliśmy, że debata toczyć się będzie wokół innowacyjnych usług informacyjnych w nauce i edukacji, w biznesie, mediach i administracji publicznej czy w różnego rodzaju instytucjach kultury. W polu naszych zainteresowań znalazły się społeczne i filozoficzne aspekty innowacyjnych technologii i usług informacyjnych, technologie semantyczne w usługach informacyjnych, mobilne usługi informacyjne, media społecznościowe, wizualizacja informacji, innowacje w organizacji wiedzy, architekturze informacji oraz w zarządzaniu informacją, a wreszcie użytkownicy informacji oraz edukacja informacyjna.

W konferencji udział wzięło niemal 100 osób, zarówno prelegentów, jak i słuchaczy. Wygłoszono 56 referatów. Mieliśmy przyjemność gościć wielu specjalistów badających problematykę informatologiczną, wywodzących się z wielu ośrodków zarówno krajowych, jak i zagranicznych, reprezentujących różne pokolenia, różne spojrzenia na dyscyplinę, różne ujęcia badawcze i kierunki jej rozwoju. Dzięki 
temu wydarzenie to, jedno z najważniejszych na informatologicznej mapie naszego kraju, odegrało rolę nie tylko forum wymiany wiedzy i doświadczeń, prezentacji nowych koncepcji czy też rozwiązań, lecz także pozwoliło na obserwację dynamiki zmian zachodzących w nauce o informacji, a wreszcie umożliwiło dokonywanie pewnych porównań pomiędzy zainteresowaniami badawczymi naszych koleżanek i kolegów z różnych ośrodków polskich i zagranicznych.

Konferencję rozpoczęło uroczyste otwarcie w Sali Konferencyjnej Biblioteki Uniwersyteckiej w Warszawie. Słowo wstępne wygłosili: prof. dr hab. Barbara Sosińska-Kalata - przewodnicząca Komitetu Programowego konferencji, prof. dr hab. Janusz W. Adamowski - dziekan Wydziału Dziennikarstwa, Informacji i Bibliologii UW oraz prof. dr hab. Wiesław Babik - z Instytutu Informacji Naukowej i Bibliotekoznawstwa Uniwersytetu Jagiellońskiego, reprezentujący stałego honorowego patrona konferencji International Society for Knowledge Organization, ISKO PL. W otwarciu konferencji wziął też udział prodziekan WDIB UW, prof. dr hab. Dariusz Kuźmina oraz przedstawiciele sponsorów konferencji.

Największa liczba gości zagranicznych przyjechała z francuskiego Uniwersytetu Charlesa de Gaulle’a - Lille 3, współpracującego z Katedrą Informatologii Laboratorium GERiiCO (Groupe d'Études et de Recherche Interdisciplinaire en Information et Communication). Dwa z wystąpień wprowadzających w problematykę konferencji wygłoszone zostały przez reprezentujące tenże ośrodek prof. Widad Mustafę El Hadi, która nakreśliła historyczny kontekst nauki o informacji i dokumentacji, oraz prof. Laurence Favier, która mówiła o ewaluacji informacji w kontekście serwisów społecznościowych. Obu paniom towarzyszyli ich doktoranci i współpracownicy, którzy również brali czynny udział w obradach, wygłaszając w czasie późniejszych sesji równoległych referaty dotyczące zachowań historyków w środowisku cyfrowym (Samia Takhtoukh), etycznych i międzykulturowych wymiarów systemów organizacji wiedzy (Tan Tran), zastosowania crowdsourcingu w humanistyce cyfrowej (dr Amel Fraisse) oraz wpływu zachowań innych użytkowników portali społecznościowych na podejmowane przez nas decyzje (Zhenfei Feng).

Ponadto gośćmi specjalnymi konferencji byli profesorowie: Gerhard Budin z Uniwersytetu Wiedeńskiego (Zentrum für Translationswissenschaft), Mieczysław Muraszkiewicz z Politechniki Warszawskiej, Tibor Koltay (Uniwersytet Eszterházy Károly w Egerze), a także przedstawiciele firm prowadzących komercyjne usługi informacyjne - Maciej Dziubecki (ALEPH Polska) i Christopher Biedermann (Emitel Ltd).

Gerhard Budin mówił o potrzebie rozwoju infrastruktury usług informacyjnych dla nauki i edukacji przez wdrażanie systemów organizacji wiedzy umożliwiających wieloaspektowy i spersonalizowany dostęp do danych badawczych w wirtualnym środowisku badawczym na różnych etapach prowadzenia badań i wykorzystywania ich wyników w edukacji. Mieczysław Muraszkiewicz zachęcał do myślenia o sztucznej inteligencji jako motorze innowacyjności, która implikuje dziś głębokie zmiany w niemal wszystkich obszarach życia społecznego. Tibor Koltay zaproponował spojrzenie na biblioteki akademickie jako ośrodki wspierające rozwój Nauki 2.0. Maciej Dziubecki poświęcił swoje wystąpienie zastosowaniu badań użytkowników w procesie projektowania bibliotecznych systemów informacyjnych, Christopher Biedermann natomiast cyberbezpieczeństwu w Internecie Rzeczy.

Pierwszy dzień konferencji wypełniony był w całości wystąpieniami w języku angielskim. Po zakończeniu pierwszej części, na którą składały się dwie sesje plenarne, moderowane przez prof. B. Sosińską-Kalatę i prof. W. Babika i obejmujące wymienione powyżej keynote'y, obradowano w czterech międzynarodowych sesjach równoległych: „e-Administracja i e-Biznes”, „e-Kultura”, „e-Nauka” oraz „Systemy informacyjne i ich użytkownicy”.

W pierwszej sesji, prowadzonej przez prof. Remigiusza Sapę (Uniwersytet Jagielloński), problemami administracji publicznej w środowisku cyfrowym zajął się Mariusz Luterek z Wydziału Dziennikarstwa, Informacji i Bibliologii UW, przedstawiając wyniki badań bibliometrycnych, których celem było ustalenie udziału informatologów w rozwoju usług informacyjnych w tym zakresie. O usługach informacyjnych dla biznesu mówili w swych wystąpieniach Erika Janiūnienè z Uniwersytetu w Wilnie i Radosław Lipiński (niezależny ekspert zarządzania wiedzą). E. Janiūnienė opowiadała o ocenie 
jakości systemów informacyjnych dla biznesu, R. Lipiński zaś zaprezentował zaprojektowany przez siebie model przepływu informacji, który stanowić powinien narzędzie wykorzystywane do wpierania procesów zmian w organizacjach.

W sesji poświęconej zjawiskom e-kultury, moderowanej przez prof. Ewę Głowacką (UMK w Toruniu), najwięcej uwagi poświęcono bibliotekom. Emmanuelle Chevry Pébayle (Uniwersytet w Strasburgu) analizowała wpływ obecności bibliotek akademickich w mediach społecznościowych na powstawanie i implementację innowacyjnych usług informacyjnych. Alicja Waszkiewicz-Raviv (WDIB UW) mówiła o wykorzystaniu elementów wizualnych w promocji bibliotek publicznych, Karolina Zawada (Biblioteka UMK w Toruniu) - o dostępnym online repozytorium surowych danych naukowych z zakresu astronomii. Projekt realizowany jest na UMK we współpracy z biblioteką uniwersytecką. Czwartym prelegentem tego panelu był Zhenfei Feng, o którego wystąpieniu była już mowa.

W moderowanej przez prof. Marię Próchnicką (UJ) trzeciej i moderowanej przez prof. Piotra Tafiłowskiego (WDIB UW) czwartej sesji tego dnia mieliśmy okazję wysłuchać, oprócz wystąpień wspomnianych już gości z GERiiCO, także referatu Sílvii Cardoso i Patrícii de Almeida (Uniwersytet w Coimbra), które zastanawiały się, czy tagowanie społecznościowe może wzbogacić katalog biblioteki oraz czy może być ono sposobem na podniesienie jakości usług w zakresie indeksowania w porównaniu do aktualnie używanego języka kontrolowanego. Odnośne badania wykonane zostały w bibliotece Escola Superior de Saúde de Santa Maria w Porto, gdzie pracuje jedna z prelegentek. W ostatnim referacie w tej sesji Pablo Benalcazar (Instytut Gospodarki Surowcami Mineralnymi i Energią PAN) omawiał zagadnienia związane z metodami pomiaru i identyfikacji gwałtownie wzrastającej ilości informacji patentowej.

W drugim dniu konferencji, w dwunastu sesjach tematycznych, zorganizowanych w trzech równoległych ciągach, obradowano w języku polskim. Sesje, podobnie jak w pierwszym dniu, moderowane były przez członków Komitetów Programowego i Organizacyjnego konferencji: prof. Mirosława Górnego (Uniwersytet Adama Mickiewicza w Poznaniu), prof. Jacka Tomaszczyka (Uniwersytet Śląski), prof. Barbarę Sosińską-Kalatę (WDIB UW), prof. Katarzynę Materską (Uniwersytet Kardynała Stefana Wyszyńskiego), dr. Marcina Roszkowskiego (WDIB UW), prof. Jadwigę Woźniak-Kasperek (WDIB UW), prof. Piotra Tafiłowskiego (WDIB UW), prof. Dianę Pietruch-Reizes (UJ), prof. Wiesława Babika (UJ), dr. Mariusza Luterka (WDIB UW) i dr Teresę Święćkowską (WDIB UW). Większość sesji składała się z trzech wystąpień i dyskusji.

Pierwszą sesję, pod hasłem „Innowacje w informacji naukowej”, otworzyła Diana Pietruch-Reizes (UJ) referatem poświęconym innowacyjnym usługom informacyjnym w nauce. Marzena Świgoń (Uniwersytet Warmińsko-Mazurski w Olsztynie) sygnalizowała kierunki zmian zachodzących w komunikacji naukowej, wzywając młode pokolenie badaczy do przeprowadzenia rewolucji w tym zakresie, zaś Teresa Święćkowska (WDIB UW) umieściła innowacje w usługach wyszukiwania informacji w kontekście prawa autorskiego. Tematyka ta kontynuowana była w sesji czwartej, w ramach której referaty wygłosili dwaj goście z Poznańskiego Centrum Superkomputerowo-Sieciowego oraz pracownik WDIB UW. Marcin Werla, kierownik Działu Bibliotek Cyfrowych i Platform Wiedzy PCSS, zaprezentował kluczowe zagadnienia związane z wykorzystaniem analityki webowej (ang. web analytics) w kontekście systemów informacyjnych, takich jak repozytoria, biblioteki cyfrowe, bazy bibliograficzne, czy systemy informacji naukowej. Michał Kozak mówił o jakości danych w systemie informacji naukowej, zaś Piotr Tafiłowski (WDIB UW) omówił projekt kartografowania wiedzy, który chciałby zrealizować w przyszłości, po uzyskaniu środków finansowych na ten cel.

Sesja druga poświęcona została użytkownikom usług informacyjnych. Remigiusz Sapa (UJ) poddał reinterpretacji koncepcję użytkownika usług informacyjnych. Monika Krakowska i Paloma Korycińska z tej samej uczelni zaprezentowały zastosowanie metody persony w badaniach informatologicznych oraz projektowaniu nowych rozwiązań zorientowanych na użytkownika. Julita Niedźwiecka-Ambroziak (UMK) mówiła o badaniach eyetrackingowych (percepcja graficznych elementów okładek książek), prowadzonych w bibliotece Wyższej Szkoły Bankowej w Toruniu. 
Sesje trzecia i szósta poświęcone były innowacjom w informacyjnych usługach bibliotecznych i bibliograficznych. Maria Próchnicka (UJ) zaprezentowała mobilne usługi biblioteczne jako przedmiot badań informatologii, dokonując przeglądu publikacji w tym zakresie. Bożena Łazowska (Centralna Biblioteka Statystyczna w Warszawie) mówiła o innowacyjnych usługach informacyjnych w kierowanej przez nią bibliotece. Dorota Siwecka (Uniwersytet Wrocławski) przedstawiła korzyści i zagrożenia, jakie niesie ze sobą wykorzystanie koncepcji danych powiązanych (Linked Data) w działalności bibliotecznej. Kontynuację tematyki innowacji w informacyjnych usługach bibliotecznych i bibliograficznych w sesji szóstej rozpoczęło wystąpienie Justyny Antosik i Anny Kamińskiej (Biblioteka Politechniki Warszawskiej), które zademonstrowały blog „Niezbędnik Chemika” jako narzędzie edukacji informacyjnej. Następnie Grzegorz Kłębek (Biblioteka Uniwersytecka w Warszawie) zaprezentował nowe oprogramowanie dla elektronicznej biblioteki Uniwersytetu Warszawskiego. Wreszcie Karolina Jaworska (Instytut Badań Literackich PAN) zapoznała słuchaczy z nową bazą danych Polskiej Bibliografii Literackiej.

W sesji piątej, poświęconej innowacjom na rynku wydawniczym, wygłoszono tylko dwa referaty: Kamila Augustyn (UWr) mówiła o cyfryzacji oferty wydawniczej i perspektywach globalnego rozwoju rynku wydawniczego w odniesieniu do książki naukowej, zaś Maria Przastek-Samokowa (WDIB UW) zaprezentowała projekt pod nazwą Obserwatorium Językowe 2.0.

Dwie popołudniowe sekwencje sesji równoległych obejmowały problematykę innowacji w kolejnych obszarach wykorzystywania usług informacyjnych. Sesja siódma, poświecona humanistyce cyfrowej, rozpoczęła się wystąpieniem Zbigniewa Osińskiego z Uniwersytetu Marii Curie-Skłodowskiej w Lublinie, który przedstawił wyniki zespołowego projektu badawczego (poza prelegentem realizowanego przez Ewę Głowacką z UMK w Toruniu, Mirosława Górnego z UAM i Małgorzatę Kisilowską z UW), poświęconego przekształceniom zachodzących w infrastrukturze informacyjnej humanistyki oraz widocznym i przewidywanym wpływom tych zmian na praktyki badawcze i publikacyjne badaczy. W drugim referacie w tej sesji Jacek Tomaszczyk (UŚ w Katowicach) zademonstrował możliwości wykorzystania bezpłatnego programu Microsoft OneNote w pracy naukowej do gromadzenia, organizowania i opracowywania różnego typu materiałów - tekstowych, graficznych i audiowizualnych.

Sesja ósma dotyczyła innowacyjnych usług informacyjnych w archiwach. Problematyka ta omówiona została w trzech referatach. Justyna Soliwoda (Narodowe Archiwum Cyfrowe) zaznajomiła słuchaczy z systemem ZoSIA - budowanym i rozwijanym przez NAC narzędziem informatycznym, przeznaczonym dla archiwów, umożliwiającym opracowywanie zbiorów materiałów archiwalnych każdego typu, w oparciu o uporządkowaną hierarchiczną strukturę opisu i przepisy archiwalne Naczelnego Dyrektora Archiwów Państwowych, a także międzynarodowy standard opisu archiwalnego ISAD(G). Monika Cołbecka (UMK) mówiła o schematach wyszukiwania informacji w zasobach archiwalnych w dobie elektronicznych pomocy archiwalnych, zaś Kamila Biernat (Archiwum Akt Nowych w Warszawie, UMK) zaprezentowała pomoce wyszukiwawcze dla użytkowników archiwów.

Interesująca była także sesja dziewiąta, trwająca równolegle pod hasłem „Nowe trendy w dyscyplinach informacyjnych”. Katarzyna Materska (Biblioteka Uniwersytetu Kardynała Stefana Wyszyńskiego w Warszawie) zaproponowała umieszczenie innowacji i procesu innowacyjności w humanistycznej, filozoficznej, a także psychologicznej perspektywie pytając, czy innowacje powinny być dla człowieka, czy też człowiek jest dla innowacji? Nowatorskie spojrzenie na dyscyplinę zaproponował Wiesław Babik (UJ), mówiący o logistyce informacji, której zadaniem staje się organizacja i koordynacja procesów przepływu informacji i wiedzy w kanałach i łańcuchach logistycznych. Strukturalistyczna koncepcja architektury informacji była przedmiotem rozważań Stanisława Skórki (Uniwersytet Pedagogiczny w Krakowie).

Ostatnią grupę sesji równoległych poprzedziło wystąpienie przedstawicieli firmy Newspoint, jednego z patronów medialnych konferencji. Firma zajmuje się monitoringiem mediów w czasie 
rzeczywistym. Reprezentujący ją Jakub Kozłowski i Kamil Niedbała omówili możliwości oferowanego przez nich komercyjnego narzędzia do monitorowania mediów. Prezentacja ta spotkała się z żywym zainteresowaniem słuchaczy.

Sesję dziesiątą, pt. „Innowacje w organizacji wiedzy” otworzył referat Barbary Sosińskiej-Kalaty poświęcony optymalizacji systemów organizacji wiedzy. Następnie Marcin Roszkowski z tej samej jednostki mówił o adnotacjach semantycznych w kolekcjach cyfrowych. Prelegent rozpoczął przemówienie od przedstawienia wniosków, które następnie, w trakcie wykładu, uzasadniał. Autorkami ostatniej prezentacji tej sesji były Jadwiga Woźniak-Kasperek (WDIB UW) i Anna Kamińska (Biblioteka Główna Politechniki Śląskiej w Katowicach), które omówiły możliwości wykorzystania języka UML w celu eliminowania wieloznaczności komunikatów, przede wszystkim komunikatów naukowych.

W sesji jedenastej, „Usługi informacyjne w gospodarce, ochronie zdrowia i kulturze”, Agnieszka Młodzka-Stybel (Centralny Instytut Ochrony Pracy - Państwowy Instytut Badawczy) przedstawiła wyniki własnego badania ankietowego, dotyczącego zastosowania technologii informacyjnych w wybranych sektorach gospodarki narodowej. Jan Kozakowski (Narodowy Instytut Zdrowia Publicznego - Państwowy Zakład Higieny, Biblioteka Naukowa, Warszawa) mówił o zasadach informowania o zdrowiu publicznym. Sesję zakończyło wystąpienie Małgorzaty Kisilowskiej, która w imieniu własnym oraz swoich współpracownic, Justyny Jasiewicz i Anny Mierzeckiej, opowiedziała o badaniach dotyczących oferty cyfrowej Narodowego Instytutu Audiowizualnego, których celem było wskazanie przyczyn niskiego zainteresowania materiałami cyfrowymi oraz zaproponowanie działań, które mogłyby spowodować pozytywne zmiany w tym zakresie.

Ostatnia, dwunasta sesja, poświęcona została nowym mediom w biznesie i kulturze. W pierwszym wygłoszonym w jej ramach referacie Łukasz Iwasiński (WDIB UW) skupił uwagę na problemie utowarowienia informacji medialnej dostępnej w sieci Internet. Następnie Anna Miotk (UKSW) mówiła o badaniach audytorium mediowego, które dostarczają informacji stanowiących podstawę dla podejmowania decyzji biznesowych. W trzecim referacie Grzegorz Gmiterek (WDIB UW) zaprezentował analizę funkcjonalności polskich aplikacji mobilnych wykorzystywanych w muzeach.

Obrady konferencji zakończyła dyskusja podsumowująca omawiane na niej zagadnienia. Podkreślano ich bogactwo, potwierdzające dynamiczny rozwój nauki o informacji. Podnoszono też potrzebę kontynuacji tej cyklicznej konferencji, która umożliwia konfrontację wyników szerokiego spektrum badań prowadzonych w różnych obszarach współczesnej informatologii przez badaczy z różnych ośrodków polskich i zagranicznych.

Wydarzenie z pewnością osiągnęło cel zamierzony przez organizatorów, zapewniając forum wymiany wiedzy, doświadczeń i przemyśleń jego uczestników. Zgodnie z intencjami organizatorów gośćmi konferencji byli zarówno akademicy, badający teoretyczne zagadnienia realizacji usług informacyjnych, jak i praktycy wdrażający je w różnych dziedzinach życia. Szczególnie cenna była możliwość wymiany doświadczeń między środowiskiem naukowym i środowiskiem różnych gałęzi biznesu informacyjnego. Spotkanie przyniosło wiele interesujących (i mamy nadzieję, że również owocnych) dyskusji kuluarowych.

Piotr Tafiłowski

Katedra Informatologii

Wydziat Dziennikarstwa, Informacji i Bibliologii

Uniwersytet Warszawski

Nadestano: 17 czerwca 2017 